\title{
Pengaruh Media Televisi untuk Mengembangkan Kosakata Anak
}

\author{
Jihan Filisyamala $^{(1)}$ \\ ${ }^{1}$ STKIP PGRI Trenggalek \\ Email: ${ }^{1}$ jfilisya@gmail.com
}

\begin{tabular}{l}
\hline Tersedia Online di \\
http://www.jurnal.unublitar.ac.id/ \\
index.php/briliant \\
\hline
\end{tabular}

\section{Sejarah Artikel}

Diterima pada 25 April 2018

Disetuji pada 10 Mei 2018

Dipublikasikan pada $13 \mathrm{Mei}$

2018 Hal. 253-259

\section{Kata Kunci:}

media televisi, kosakata, anak

\section{DOI:}

http://dx.doi.org/10.28926/briliant .v3i2.180

\begin{abstract}
Abstrak: Tujuan dari artikel ini adalah untuk menganalisis penggunaan media audio visual televisi terhadap peningkatan kosakata pada anak. Salah satu bagian yang mendukung perkembangan bahasa anak adalah menstimulasi sejak dini kosakata-kosakata baru pada anak. Hal yang penting untuk mempermudah anak melakukan komunikasi dengan lingkungannya yaitu dengan menguasai kosakata. Media audio visual televisi memiliki dampak yang cukup signifikan terhadap pengembangan kosakata, jika mereka melihat program pendidikan dan memperhatikan atau membatasi waktu yang digunakan untuk melihat acara-acara di televisi setiap hari.
\end{abstract}

Salah satu alat yang penting untuk digunakan setiap orang dalam berkomunikasi yaitu bahasa. Manusia mengembangkan dirinya dengan mengadakan kontak sosial melalui bahasa. Penguasaan kemampuan bergaul yang dimiliki setiap anak dapat dimulai dengan memiliki kemampuan berbahasa. Melalui kemampuan bahasa yang baik, seorang anak akan mudah bergaul dalam lingkungan sosialnya. Jadi, kemampuan berbahasa sangatlah penting untuk dimiliki setiap anak dalam memenuhi kebutuhan hidupnya sebagai makhluk sosial. Melalui bahasa akan diperoleh berbagai informasi, pesan, petunjuk dan pengetahuan yang sangat diperlukan bagi kehidupan, oleh karena itu penguasaan bahasa adalah hal yang diperlukan dalam berkomunikasi dan meningkatkan kemampuan bersosialisasi dalam kehidupan manusia. Seperti yang dikatakan Hitipeuw (2009: 23) bahwa berbagai ide, konsep, rencana, dan sebagainya yang dapat didapatkan melalui alat komunikasi yaitu bahasa.

Komunikasi yang efektif dilakukan adalah dengan berbicara. Bicara adalah bentuk bahasa dengan menggunakan kosakata dan artikel untuk menyampaikan maksud. Kosakata yang telah dikuasai seseorang mencerminkan pola keterampilan orang tersebut dalam berbahasa. Untuk itu diperlukan usaha yang dapat meningkatkan ketrampilan anak secara optimal. Membaca memiliki dampak terbesar pada perkembangan kosakata anak-anak, tetapi usaha yang lain juga penting (Tompkins, 2011: 54).

Salah satu usaha untuk mengembangkan kosakata anak adalah dengan menggunakan media. Banyak sekali pilihan media yang digunakan sebagai penunjang dalam membantu untuk mengembangkan kosakata anak. Media televisi dapat meningkatkan minat, karakter serta imajinasi pada anak. Penggunaan media 
audio visual televisi merupakan media yang dapat berpengaruh terhadap keterampilan berbahasa anak yaitu semakin bertambahnya kosakata anak. Anakanak begitu tertarik dengan media audio visual televisi daripada media lainnya karena dari segi karakteristik yang dimiliki dari media televisi memiliki beberapa kelebihan dibandingkan dengan media cetak maupun media dengar, sehingga anak-anak sangat menyukai.

\section{PEMBAHASAN \\ Media Televisi}

Media merupakan alat perantara yang membantu dalam menyampaikan atau menyajikan suatu materi, sehingga diharapkan tercapainya suatu tujuan yang diinginkan. Seperti yang dikatakan oleh Smaldino, dkk. (2011: 7) bahwa media merupakan alat perantara komunikasi. Tujuan dari penggunaan media adalah untuk membantu mempermudah dalam kegiatan belajar dan berkomunikasi. Penggunaan media dalam pembelajaran dapat membantu dalam hal memperjelas penyajian materi dan informasi sehingga diharapkan dapat memotivasi belajar anak dan mengarahkan perhatian anak pada saat pembelajaran. Didukung dengan pendapat Arsyad (2013: 3) bahwa media dalam kegiatan pembelajaran merupakan alat untuk membantu dalam penyampaian pesan-pesan pembelajaran. Dari beberapa pernyataan tersebut, dapat disimpulkan bahwa media merupakan suatu penghubung atau perantara, baik itu berupa alat atau bahkan serta kegiatan yang digunakan untuk mempermudah penyampaian pesan atau informasi.

Media dikelompokkan menjadi tiga, yaitu media audio, media visual, dan terakhir media audio visual. Ketiga media yang dikembangkan mempunyai ragam yang bervariatif, seperti media audio dapat menggunakan radio. Selanjutnya untuk media visual dapat menggunakan gambar-gambar dan media audio visual salah satunya dapat menggunakan televisi. Pemilihan media sebagai pendukung dalam kegiatan belajar mengajar harus mempertimbangkan dari segala aspek, sehingga media tersebut dapat diberdayakan seefektif mungkin dan di sesuaikan dengan karakteristik anak.

Media memiliki berbagai macam bentuk dan televisi merupakan media audio visual yang dapat meningkatkan minat, karakter serta imajinasi. Televisi merupakan media audio visual penangkap siaran bergambar. Kata televisi bermula dari kata tele yang artinya jauh dan vision yang berarti tampak. Jadi, televisi dapat diartikan tampak atau dapat terlihat dari jarak jauh. Arsyad (2013: 50) mengatakan bahwa televisi adalah alat elektronik yang dapat mengirimkan gambar hidup maupun gambar mati bersama suara melalui suatu ruang. Media televisi merupakan media audio visual yang lebih banyak menarik perhatian anak karena adanya perpaduan antara suara dan gambar yang membuat mereka lebih tertarik untuk mengetahui apa yang dilihat dan sekaligus mereka dengar. Anakanak sangat tertarik dan menyukai dengan media televisi daripada media lainnya, tidak terlepas dari karakteristik yang dimiliki media televisi dibandingkan dengan media lainnya seperti media cetak maupun media dengar.

Media televisi sekarang ini merupakan media yang mudah dijumpai dan dimiliki oleh semua orang, sama halnya dengan media lainnya seperti majalah, koran, radio, atau internet. Televisi sebagai alat elektronik yang memancarkan rekaman dari setasiun pemancar kepada para penonton, rekaman-rekaman yang dipancarkan dapat berupa informasi berita, pendidikan, hiburan, dan lain-lain. 
Saat ini dalam dunia pendidikan, media televisi dibutuhkan untuk membantu memenuhi kebutuhan yang berkaitan dengan pencapaian tujuan pembelajaran, dengan harapan segala kebutuhan tersebut dengan mudah dijangkau melalui siaran dari udara dan dapat dihubungkan melalui satelit meskipun melalui jarak yang jauh. Seperti pendapat Arsyad (2013: 53) bahwa televisi pendidikan tidak hanya memberikan hiburan tetapi yang lebih penting adalah menyajikan tontonan yang mendidik. Televisi bukan merupakan barang yang mewah dan dapat kita temui dengan mudah. Media layar kaca televisi sudah menjadi salah satu barang yang harus dipenuhi bagi kehidupan masyarakat untuk mendapatkan informasi maupun hiburan.

\section{Kosakata Anak}

Pengertian dari kosakata merupakan bagian dari suatu bahasa tertentu atau himpunan kata. Setiap orang perlu mengembangkan kosakata dalam dirinya, baik dari pengembangan kemampuan seseorang maupun proses pembelajaran suatu bahasa. Selain itu, penambahan kosakata dampak yang signifikan terhadap pemahaman bacaan (Tompkins, 2011: 54).

Selanjutnya menurut Hart \& Risley (dalam Coleman, 2007: 13) berpendapat bahwa mengembangkan kosakata sangat penting untuk keberhasilan masa depan anak-anak di sekolah. Dalam rangka untuk mendapatkan kata-kata baru, anak-anak perlu mendengar berkali-kali dan berlatih menggunakan kata. Beck (dalam Coleman, 2007: 13) berpendapat bahwa ajaran kosakata harus "kuat" dan terdapat beberapa kriteria untuk memilih kata-kata untuk mengajar anak-anak: (a) Kata harus dipahami; (b) Kata dapat dijelaskan dalam bahasa yang sederhana; dan (c) Kata memiliki banyak kemungkinan untuk digunakan.

Banyaknya kosakata yang dimiliki seseorang berpengaruh pula terhadap banyaknya ide dan gagasan yang dikuasai seseorang, oleh karena itu penguasaan kosakata merupakan hal penting dalam mencapai penguasaan bahasa. Thomkins (2011: 54) mengatakan bahwa kosakata anak-anak tumbuh sekitar 3.000 kata per tahun, atau sekitar 7 sampai 10 kata-kata baru setiap hari. Anak 5 tahun mengenali 5.000 kata, dan pada saat mereka lulus dari sekolah tinggi, kosakata mereka bisa mencapai 25.000 sampai 50.000 kata atau lebih. Tampak jelas bahwa untuk belajar kata-kata pada tingkat yang produktif, anak-anak belajar kata-kata baik di dalam maupun di luar sekolah, dan mereka belajar banyak kata secara kebetulan tidak melalui instruksi yang eksplisit.

Anak-anak mengembangkan pengetahuan tentang kata secara bertahap, mulai dari tidak tahu kata sama sekali hingga mengetahui keseluruhan kata. Mereka tahu banyak arti kata dan dapat menggunakannya dalam berbagai cara (Nagy dalam Tompkins, 2011: 54). Berikut adalah empat tingkatan pengetahuan kosakata: (1) Ketidakbermaknaan kata. Anak-anak tidak mengenali kata; (2) Pemahaman awal. Anak-anak telah melihat atau mendengar kata atau bisa mengucapkannya, tapi mereka tidak tahu artinya; (3) Pemahaman kata parsial. Anak-anak tahu satu arti kata dan dapat menggunakannya dalam kalimat; dan (4) Pemahaman kata secara lengkap/sempurna. Anak-anak tahu lebih dari satu arti kata dan dapat menggunakannya dengan beberapa cara (Allen dalam Tompkins, 2011: 55).

Perkembangan bahasa anak perlu diberikan rangsangan agar tumbuh dengan seimbang. Khususnya pada penguasaan kosakata. Pertumbuhan kosakata 
anak dipengaruhi oleh lingkungan. Semakin banyak kosakata, semakin banyak kemungkinan anak memahami sehingga tuturan yang dihasilkan anak pun semakin kaya. Oleh karena itu, perlu bagi guru memberikan kata yang memperkaya kosakata anak didiknya. Penguasaan kosakata perlu terus menerus dikembangan dengan memperbanyak dan memperluas kosakata yang disesuaikan dengan tuntutan usia. Tarigan (dalam Rahmawati, 2011: 3) berpendapat bahwa ada dua cara bagi anak untuk mempelajari kosakata, antara lain: (a) Kosakata diperoleh dari mendengarkan dari orang lain, yaitu orang tua, teman sepermainan, televisi, radio, tempat bermain, toko, pusat perbelanjaan dan anak-anak yang lebih tua; (b) Kosakata diperoleh dari pengalaman anak sendiri, misalnya mengatakan benda-benda, merabanya, menciumnya, memakannya dan meminumnya. Selanjutnya menurut Tarigan (dalam Rahmawati, 2011: 3) juga mengatakan bahwa kualitas ketrampilan berbahasa seseorang jelas bergantung kepada kuantitas dan kualitas kosakata yang dimiliki. Semakin kaya kosakata yang dikuasai oleh anak, maka semakin besar pula kemungkinan ketrampilan berbahasanya. Jadi, diharapkan anak dapat mengembangkan penguasaan kosakatanya dengan cara mengetahui sebanyak-banyaknya perbendaharaan katakata dalam setiap bahasanya.

\section{Pengaruh Media Televisi untuk Mengembangkan Kosakata Anak}

Media televisi merupakan salah satu media audio visual yang banyak diminati oleh masyarakat, hal tersebut ditunjukan dengan banyaknya beberapa stasiun televisi yang hadir baik dari pihak swasta dengan skala nasional maupun stasiun televisi lokal dengan penyiaranya dalam lingkup di daerah tertentu saja. Televisi bisa dibilang sudah menjadi kebutuhan yang diperlukan manusia. Melalui karakteristik yang dimilikinya, bermacam-macam acara televisi yang ditayangkan bisa diterima dengan baik oleh indera manusia. Televisi berusaha menjangkau berbagai latar belakang budaya, gender, dan kehidupan sosial melalui berbagai program acara seperti berita, kuis, infotaimen, kartun, film seri, sinetron, dan lainlain. Dengan demikian televisi tidak hanya masuk ke dalam dunia dewasa, tetapi juga masuk ke dunia anak-anak dan remaja dengan cara mencoba menghadirkan dunia hiburan yang sesuai dengan masa-masa itu.

Penggunaan media televisi dapat berpengaruh terhadap keterampilan berbahasa anak yaitu semakin bertambahnya kosakata anak. Tompkins (2011: 56) berpendapat bahwa televisi memiliki pengaruh terhadap pengembangan kosakata, terutama untuk anak 4 dan 5 tahun, jika mereka melihat program pendidikan dan memberi batasan waktu yang digunakan untuk menonton acara di televisi setiap hari. Kosakata merupakan pendukung pada aspek perkembangan bahasa pada anak. Semakin banyak seorang anak menguasai kosakata maka akan banyak pula bahasa yang diungkapkannya dalam berkomunikasi dalam lingkungan sosialnya nanti. Saat ini di negara-negara maju semakin berkembang pesat pembuat program yang sadar betul dengan daya tarik dari televisi bagi anak-anak. Contohnya film kartun anak-anak yang diproduksi oleh perusahaan Nickelodeon yang digemari oleh anak-anak.

Anak tidak hanya melihat dan memerhatikan kata apa yang diucapkan orang di televisi, tetapi juga cara melafalkannya. Dengan demikian televisi membantu anak menambah kosakata sekaligus belajar lafal dan tata bahasa. Kemampuan berbahasa yang didapat dari menonton TV ini dapat diterapkan anak 
pada kehidupan sehari-hari. Tentunya bahasa yang sesuai dengan umur anak. Anak bisa terlibat dalam pembelajaran mandiri dengan melihat program televisi pendidikan (Smaldino, dkk., 2011: 14).

Untuk mengembangkan pemerolehan kosakata anak yaitu dengan cara menyuguhkan tontonan melalui acara-acara televisi yang berorientasikan pada pendidikan dan pengembangan kosakata anak. Berikut ini beberapa acara yang direkomendasikan serial televisi pendidikan bagi anak-anak, antara lain: (1) Program Between the Lions (PBS Kids), serial televisi ini tentang keluarga singa yang menjelajahi perpustakaan. Anak-anak singa tersebut mengalami keajaiban dari buku sambil mempelajari kosakata, phonics dan pemahaman; (2) Dora, the Explorer, Dora adalah anak 7 tahun yang suka berpetualang, dia dan temantemannya memecahkan tebak-tebakan dan teka-teki selama berpetualang.Program kartun interaktif ini mengajarkan banyak kosakata dan keterampilan literasi; (3) The Electric Company, dalam serial televisi ini ada empat remaja pahlawan super literasi bertanding dengan penjahat lingkungan. Setiap episode mengajarkan empat atau lima kosakata, dan program ini mencakup unsur-unsur web interaktif dan game online; (4) Go Diego Go, Diego anak usia 8 tahun adalah pahlawan aksi petualang yang mencintai binatang (dia sepupu Dora the Explorer). Dalam setiap episode, ia menggunakan keterampilan observasi dan alat-alat ilmiah untuk menyelamatkan hewan yang dalam kesulitan; (5) Little Einsteins, Empat anak memulai sebuah misi di setiap episode untuk memecahkan masalah atau membantu teman. Seri ini dirancang untuk mengajak menyukai seni dan musik; dan (6) Sesame Street, yang menarik dari seri ini yaitu menampilkan Big Bird dan Elmo menggabungkan pendidikan dan hiburan menggunakan animasi, boneka, dan aktor hidup untuk mendorong imajinasi, mengajarkan membaca dan konsep matematika, dan membangun keterampilan sosial (Tompkins, 2011: 58).

Dari daftar yang direkomendasikan serial televisi pendidikan bagi anakanak pada uraian di atas, terdapat film kartun anak-anak yang diproduksi oleh perusahaan Nickelodeon seperti Dora the Explorer. Metode yang digunakan dalam konsep kartun Dora ini didasarkan pada Teori Multiple Intelligences yang dikemukakan oleh Howard Gardner (dalam Armstrong, 2009: 32) dimana anakanak akan tumbuh cerdas dengan belajar sambil bermain. Menonton acara petualangan Dora the Explorer bukan sekedar menonton film kartun biasa. Disini ada aspek kecerdasan seperti logical/mathematical, musical/auditory, andbodily/ kinaesthetic. Film kartun Animasi Dora the Explorer mempunyai pengaruh positif pada anak-anak karena terbukti dengan menonton film kartun animasi tersebut dapat menambah kosakata baru dalam bahasa.

Dampak positif yang dimiliki media telivisi juga dibarengi dengan adanya dampak negatif. Dampak negatif dari televisi timbul karena ketidakmampuan seorang anak membedakan apa yang ia lihat di media televisi dengan apa yang ada dikehidupan nyata. Untuk itu pendampingan orang tua sangat diperlukan. Orangtua harus mampu mengenali aspek-aspek positif televisi dan menyuguhkan kepada anak. Semua aspek positif dari televisi bisa terlewat begitu saja, karena anak belum mampu menggalinya sendiri. Selain pendampingan, seleksi terhadap acara televisi, wajib dilakukan. Orang tua berperan dalam memilih acara yang aman dan sesuai dengan umur anak. Terkait dengan seleksi acara, pembatasan waktu menonton juga menjadi hal penting. Membatasi anak menonton televisi maksimal hanya dua jam sehari, AAP 
(American Academy of Pediatrics) dalam publikasi di jurnal ilmiahnya, "Pediatrics" menyatakan bahwa anak di bawah usia 2 tahun tidak dikomendasikan untuk menonton TV. Sedangkan anak yang berusia lebih dari 2 tahun atau lebih tua, AAP memperbolehkan anak usia tersebut menonton televisi yang menyiarkan acara yang edukatif dan tidak menampilkan kekerasan dan juga harus membatasi waktu yang digunakan menonton TV sekitar satu atau dua jam saja.

Persentasi acara televisi di Indonesia yang menyuguhkan tontonan atau acara yang edukatif masih sangat sedikit. Acara yang baik seperti serial televisi pendidikan bagi anak-anak yang telah disebutkan di atas masih minimal sekali, dan memang masih kurang diperhatikan oleh pihak pengelola televisi. Siaran televisi di Indonesia juga tidak sebanyak acara televisi di luar negeri, kecuali apabila keluarga berlangganan televisi kabel. Sekarang ini di Indonesia media televisi belum banyak memberi pengaruh seperti di negara-negara maju lainnya seperti di Inggris atau Amerika Serikat, sehingga diharapkan masyarakat dan pemerintah kususnya pada Komisi Penyiaran Indonesia mulai memperhatikan tontonan atau acara yang mendidik atau memberikan pengaruh yang baik pada anak maupun pada semua golongan usia.

\section{KESIMPULAN}

Keterampilan bergaul dengan orang lain dalam lingkungan sosialnya perlu dimiliki anak. Penguasaan ketrampilan tersebut dimulai dengan memiliki kemampuan berbahasa. Berbicara sendiri merupakan bentuk bahasa dengan menggunakan artikulasi dan kosa kata untuk menyampaikan maksud. Oleh karena itu, diperlukan usaha yang dapat meningkatkan ketrampilan anak secara optimal dengan cara mengembangkan kosakata pada anak yaitu melalui media audio visual televisi. Melalui media televisi, anak akan memerhatikan kata-kata yang diucapkan orang di televisi dan bagaimana cara orang mengucapkannya. Dengan demikian melalui televisi, membantu anak belajar menambah kosakata baru dengan memberikan tontonan melalui acara-acara televisi yang berorientasikan pada pendidikan dan pengembangan kosakata anak. Kemampuan berbahasa yang diambil dari televisi dapat digunakan anak pada kehidupan sehari-hari.

\section{SARAN}

Dalam penggunaan televisi pada anak, disarankan para orang tua agar melakukan pendampingan dengan cara mengenali aspek positif televisi, selektif dalam memilih acara televisi untuk anak, dan membatasi waktu menonton. Selanjutnya, bagi peneliti lain disarankan dapat mengungkapkan lebih dalam lagi tentang pengembangan kosakata anak dan menemukan media lain yang dapat membantu dalam perkembangan kosakata anak.

\section{DAFTAR RUJUKAN}

Armstrong, T. 2013. Kecerdasan Multipel di Dalam Kelas. Edisi Ketiga. Terj. Dyah Widya Prabaningrum. Jakarta: Indeks.

Arsyad, A. 2013. Media Pembelajaran. Jakarta: Rajagrafindo Persada.

Coleman G.A. et al. 2007. Preschool Experiences in Early Language and Literacy: Teacher's Guide. New York: Project STARS.

Hitipeuw, I. 2009. Belajar \& Pembelajaran. Malang: Universitas Negeri Malang. 
Rahmawati, N. 2011. Pengaruh Media Pop-Up Book Terhadap Penguasaan Kosakata Anak Usia 5-6 Tahun Di TK Putera Harapan Surabaya. Jurnal Online Universitas Negeri Surabaya. http://www.scribd.com/doc/203029 041/PENGARUH-MEDIA-POP-UP-BOOK-TERHADAP-PENGUASA AN-KOSAKATA-ANAK-USIA-5-6-TAHUN-DI-TK-PUTERA-HARA PAN-SURABAYA\#scribd.

Smaldino, S.E. et al. 2011. Instructional Technolohy \& Media For Learning. Edisi kesembilan. Terj. Arif Rahman. Jakarta: Kencana Prenada Media Group.

Tompkins, G. E. 2011. Literacy in the Early Grades. New York: Pearson. 